\title{
An Analysis Of The Relationship Between Distance From Campus And GPA Of Commuter Students
}

\author{
Danielle Nelson, Saginaw Valley State University, USA \\ Kaustav Misra, Ph.D., Saginaw Valley State University, USA \\ Gail E. Sype, Ph.D., Saginaw Valley State University \\ Wayne Mackie, Ph.D., Saginaw Valley State University, USA
}

\begin{abstract}
A variety of factors influence a student's ability to succeed in college and complete a degree program. Students who live on-campus, at least during their freshman year, have been shown to be more likely to complete their degrees than are students who live off-campus. Students who are commuters may have more demands on their time and may have fewer opportunities to develop a strong commitment to their studies and to their university. It may be hypothesized that students who live farther away from a campus may find it more difficult to attend classes and to complete outside tasks required by their classes. In an initial test of this hypothesis, an examination of the relationship between a commuter student's distance from campus and his/her overall grade point average is assessed. Results do not support this hypothesis. Possible reasons for this finding and directions for future research are discussed.
\end{abstract}

Keywords: Distance; GPA; Education; Commuter Students

\section{INTRODUCTION}

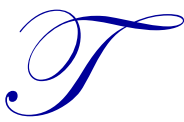

he population of commuters on college campuses continues to increase. According to a study called Time is the Enemy, only $25 \%$ of college students attend full-time and live on-campus. Three-quarters of U.S. college students, according to this report, have to juggle work, families and school and also commute to classes. Further, this report indicates that only a quarter of the students who attend part-time ultimately complete college, and students who are poor and/or students of color face additional barriers to completing their college educations. Bozic (2008) confirmed these results in his analysis of factors influencing the ability of students to complete their degree programs.

Schools that have not been known for actively enrolling a significant amount of non- residential students are now recognizing that, whether they sought them out or not, the population of commuter students has increased at their universities and colleges. Results described above indicate that being a commuter may reduce the likelihood of completing a degree. Overall, a student's success is affected by what obligations and outside demands are influencing his or her chances for educational success or failure. Another factor, not specifically addressed, is related to where that student is living and how great a distance that student must cover in order to attend the university. If a relationship between a student's length of commute and his or her academic performance is found, then institutions can explore possible interventions or activities that would serve the needs of these commuter students. It is the goal of this study to assess whether distance from campus plays a role in student success, as described by overall grade point average (GPA). 


\section{LITERATURE REVIEW}

\subsection{Skills and Qualities that are Related to Effective Student Performance}

This research required an investigation of the key variables affecting a student's academic achievement and persistence. Significant research has been conducted on the various elements affecting a student's academic performance in order to understand what leads to student success. One of the major measurements of student performance is the student's grade point average (GPA). This is the primary outcome measure for this study. Our goal is to assess the positive or negative effect that variables such as age, gender, or student living situation have on this outcome measure. "Living situation" would include whether a student is a commuter and the distance that a commuter has to travel to campus.

One broad set of variables that can impact college students' success includes students' attitudes, experiences, and knowledge. Bean and Bradley (1986) looked at students' satisfaction and performance levels and found that students who performed well had higher levels of satisfaction than did those who performed at lower levels. This finding was especially pronounced for female students. We may infer from this that when a student's skills, experiences, etc. allow him or her to be a more successful student, s/he will be encouraged to continue to be a more successful student due to the satisfaction that this success provides. The positive feedback provided by grades (as one component of feedback from instructors) may enhance students' feelings of positive connection with the university and encourage students to persist in their studies in order to maintain access to this positive feedback.

The first years of college are a transitional time in young adults' lives and their living arrangements may affect more than just their grades. Daily living skills, time management capabilities, and personal accountability are critical to the success of students who live on campus (Bozic, 2008). Living off campus allows for a student's time to be directed towards other obligations which may hinder the opportunity for a student to "develop a sense of place" (O'Toole, Peterson and Wetzel, 1999). This sense of place may be essential to a student's developing a sense of selfefficacy as a student. There are, however, other variables that can either take away from or complement a student's time and may have an effect on academic success as well. Whether or not students progress through their college careers can depend upon influences such as their social lives, financial and family support, academic commitment, and employment.

Employment status has also been hypothesized to have a concrete effect on student engagement. The more time students spend working, the less time they have for academic-related activities and obligations (Bozick, 2007). Time constraints such as working part-time, or in some cases full-time jobs, require students to make trade-offs within their academic lifestyles, and forces them to set their priorities accordingly. Students who are single may have fewer obligations related to their home life which is why being single was found to contribute to student retention rather than attrition (O'Toole et al., 1999).

Whether students are financially stable also may have an effect on the persistence and in turn, success at any given university. Academic, social, and financial support has been found to promote success of a college student. In order for a student to persist through college, he or she must be prepared to overcome any financial obstacles encountered along the way. Financial support, whether it comes from his or her own earnings, parents, or a spouse, has an impact on how involved a college student can be (Tinto, 1999).

Both student engagement and interaction with the academic environment have been identified as critical factors influencing a student's persistence through college. Two key theorists, Tinto (1999) and Astin (1984), both approach the concept of student success with an emphasis on the persistence levels a student possesses. Tinto is identified in several institutional studies as the 'founder of the student integration model' and his work assesses the impact of offcampus and on-campus residency. As described in the integration model that Tinto devised, student engagement levels influence both how capable students are at adapting to the school's people, processes, and teaching, and student engagement also impacts the success that students achieve at their university (Pascarella, Terenzini and Wolfe, 1986). Students who have adapted to the norms of their university may feel that they fit in better at that university and thus are more engaged with their university. That feeling of "fit," the sense that "I am where I am supposed to be," may encourage students to persist and therefore to acquire their degrees. 


\subsection{Differences Between Skills/Qualities of Residential and Commuter Students}

Lutta (2008) assessed a number of factors related to the retention of traditional-age students at a university in the southern U.S. He found that students who were not retained (i.e., who did not continue their involvement with the university) were less likely to be involved in a campus organization (the only on-campus organizations at this school were the Greek fraternities/sororities). The non-returning students also had slightly lower GPAs upon entry to the university. Lutta also found that over $75 \%$ of the students who did not return to school for their third year lived offcampus; i.e., they were commuter students.

Newbold, Mehta and Forbus (2011) conducted an analysis of commuter vs. residential student performance which indicated that there were several key differences between the two groups. Their results indicated that commuting students tended to be older and more likely to come from blue-collar families. Newbold et al. hypothesized that these families are less familiar with the higher education system. Many of these students are also more likely to be first-generation-in college students who may be less well prepared academically than their peers. Newbold et al. also indicated that commuter students live more of their lives in the off-campus setting, and thus their support resources are likely to be off-campus as well. Students living on campus have greater access to counselors, advisers, and fellow students when faced with an academic problem. When Newbold et al. conducted a study of students at a southwestern university, they found that commuter students were, on average, older than residential students, worked more hours, had higher personal incomes, and felt less of a sense of identification with the university they attended. Newbold et al. also encouraged additional research into differences between commuters and residential students in order to enable universities to develop programs that more effectively served the needs of each group.

Another study indicating that residential students had advantages over commuter students was the research of Kuh, Gonyea, and Palmer (2001). Their results indicated that living on campus was related to gains in social and personal competence. That enhanced level of competence may help students living on campus to be more successful in their courses. Conversely, commuters have been found to have slightly lower levels of interaction with faculty members and were less likely to be involved in co-curricular activities such as clubs, internships, and study abroad experiences (Kuh, Gonyea, and Palmer, 2001). When commuter students compare themselves to their peers on campus, they may feel that they are at a disadvantage in terms of skill development. They may also feel that they are not involved in the "life" or the essential activities of the school. This may discourage these students and influence their commitment to continuing their educations.

Guerrero (2010), in an analysis of factors that influenced student retention at a southwestern university, identified several factors that influenced students' continuing commitment to remaining enrolled in college. Among the factors identified, part-time status of students was found to have a significant relationship with the possibility of dropping out of college. Guerrero reported that students who attended part-time were nearly $230 \%$ more likely to drop out than were full-time students. Students who attend part-time may do so because they cannot afford to attend fulltime; and students attending part-time are by definition off-campus residents, because most colleges and universities allow only full-time students to live on campus.

In another example of how commuter status may affect student skills, Nonis, Philhours and Hudson (2006) conducted an analysis of business students' study habits. They divided the research subjects into two groups: campus-centered students (CCS) and life-centered students (LCS). While there was no mention of where each group of students lived, it is reasonable to hypothesize that campus-centered students were more likely to live on campus while life-centered-student were more likely to live off-campus. The results of Nonis et al.'s analysis indicated that campus-centered students had slightly higher GPAs and higher self-reported levels of academic performance.

Subsequent research conducted by Nonis and Hudson (2010) found that as students' time at work increased, the students' academic performance levels decreased. Nonis and Hudson also found that students' GPAs were not related directly to the amount of study time that a student was able to commit to. To explain this, Nonis and Hudson hypothesized that amount of study time may not be the key variable, but instead that ability to concentrate may be the better predictor of academic performance. To the extent that commuter students have more non-school commitments and family activities to attend to, their performance may be impacted by constraints on their ability to focus on their scholastic tasks. 
Student engagement therefore is a positive outcome that enhances the student's commitment to the educational process. There may also be barriers that reduce the likelihood of students' completion of their degrees. One example is where students live: Both Bozick (2008) and Guha and Leonard (2001) found that students who lived with their parents were less likely to persist past the first year of college compared to on-campus students. Students who live with their parents cannot avail themselves of whatever benefits may be derived from living on campus as a freshman (Lutta, 2008).

Another problem highlighted in the literature is that commuting students had the least amount of economic resources. Bozic (2008) also found that students who worked 20 hours a week or more and who lived at home were more likely to leave college during their freshman year. Bozick found that students from low-income families are more likely to work for school-related expenses and to live at home during the first year of college. As he put it, these are "cost-saving strategies that, in some cases, impede their (students') chances of continuing into the second year." Students attempt to limit costs by living at home but living at home makes their connection to the university and to the educational process more tenuous.

Therefore, we know that working away from campus, traveling to campus for school, financial resources (or lack thereof), and enrolling part-time for college courses have all been shown to have negative impact on students' continuing success; students who live off-campus have fewer opportunities for engagement and for integration into campus life.

Although there are several possible reasons why commuters may be less successful as students, past research has not assessed whether the distances that students have to travel will influence their success in the post-secondary environment. If there are connections found between the distance to campus that a student must travel and that student's academic success, then options should be identified that could enhance commuter students' learning.

This literature review has identified a number of factors that can influence the likelihood of a commuter student completing a baccalaureate degree. While factors such as part-time vs. full-time enrollment in college, economic self-sufficiency, and engagement with the university have all been identified as conditions which can impede a student's progress toward a degree, no research has been conducted to assess whether the distance that a student commutes affects his or her likelihood of completing a college degree. This study is a first step in answering that question. We will look at the distance that a student must travel to campus and assess the relationship between the distance that a student must commute and student OGPA (overall grade point average). Particularly in environments where winter travel can be treacherous, students who have to commute longer distances face significant hurdles in maintaining good attendance in their classes. We are assuming that a student's GPA is a partial indicator of his or her engagement with the academic environment and is also a partial indicator of the student's likelihood of longterm academic success. The more time a student has to spend commuting, the less time $\mathrm{s} / \mathrm{he}$ has for studying or working with peer groups, etc. Therefore, we are hypothesizing that the longer a student's commute is, the lower his or her GPA is likely to be.

\section{DATA}

In this study, we collected students' records from Saginaw Valley State University. Saginaw Valley State University is a small-to mid-sized university located in east-central Michigan. This university enrolls approximately 10,000 students annually. A significant percentage of the students enrolled at this university are commuters, particularly upper-level students who may be enrolled in professional programs or in graduate programs.

For analysis of our hypothesis we employed cross sectional data for 403 students after dropping observations with missing values. The sample in this study included college students who were enrolled in courses for the 2011-2012 academic year. This sample is not claimed to be representative of college students as a whole; it was a convenience sample that provided an inexpensive and readily accessible source of data.

The data required for this study included students' personal, academic and socio-economic characteristics. The students' personal identification information was removed from the data set to ensure student anonymity. The overall grade point average (OGPA) was employed as a dependent variable in this study along with other 
independent variables. We are using OGPA as an initial measure of student performance. Obviously, this variable does not indicate the likelihood of a student completing a degree, but this is the only assessment tool available in our data set. The mean OGPA is 2.98 with a standard deviation of 0.61 .

The set of control variables included in this investigation are as follows:

Cumulative Credit Hours: Total credits earned were used to determine a student's semester classification. This variable is used to measure the student's continuing interest in school and progress toward a degree. On average a student had completed about 76.91 credit hours with values ranging from 3 cumulative credit hours to 216 cumulative credit hours. The distribution of this variable indicates that this data set included students from freshman to senior levels.

Race: The student population at this campus is highly skewed to Caucasian and the numbers of members of other races are significantly lower. Therefore, we categorize this variable as 0 and 1 , that is a white student is indicated as value "0" and all other races will be identified as value "1". Marital Status-This is also a binary variable indicating whether the student is not married (0), or is married (1). Only 7 percent of the students whose data were analyzed were married.

Age: This variable indicates the age of the student whose information was used. The mean student age is 23 years with a standard deviation of 5.63 years. Reported ages varied from 18 years to 72 years.

Gender: Categorical variable used to account for differences in academic success rates between sexes and is represented by males (0) and females (1). Fifty-six percent of the students in this sample are female.

High School GPA (HSGPA): We used HSGPA to measure students' cognitive abilities. This variable indicates whether academic success in college can be predicted by the high school-level academic success of a student. The mean HSGPA is 3.34 with a standard deviation of 0.51 points.

Distance: The hypothesis related variable in this study we used is the commuting distance. This variable indicates the shortest route from the student's residency to the university campus. This variable is computed and measured in miles. Two groups of students are of importance for this study: commuting students and residential students. Students were considered residential if they lived in the dormitory or other campus housing. This is a key variable of interest in this study since it indicates how commuting distance may be related to students' OGPA. On average a typical student travels about 26.13 miles from their residence to campus with a standard deviation of 30.77 miles. Not surprisingly, this variable ranges from 0 miles to 120 miles; which means there are a number of students who are living on campus and on the other hand, there are students who are traveling a significant distance to attend classes. The descriptive statistics for these variables are found in Table 1.

Table 1. Descriptive Statistics

\begin{tabular}{lrr}
\hline \multicolumn{1}{c}{ Variable } & Mean & Std. Dev. \\
\hline Overall Grade Point Average (OGPA) & 2.98 & 0.61 \\
Distance & 26.13 & 30.77 \\
Cumulative Credit Hours & 76.91 & 39.23 \\
White & 0.78 & 0.41 \\
Black & 0.09 & 0.29 \\
Married & 0.08 & 0.26 \\
Age & 23.18 & 5.64 \\
Female & 0.56 & 0.49 \\
High School Overall Grade Point Average (HSGPA) & 3.34 & 0.51 \\
\hline
\end{tabular}

Observations $(\mathrm{N}=403)$ 


\section{METHODOLOGY}

The primary goal of this paper is to understand how travelling distance is related to a student's overall grade point average. We have only one year of cross sectional data, so using the Ordinary Least Squares technique to evaluate the hypothesis of this paper is the most appropriate methodology.

\section{RESULTS}

Table 2 presents the results of the cross-sectional data analysis. Overall, there are four control variables that appear to be significant, which are cumulative credit hours, marital status, age, and HSGPA. The cumulative credit hours variable appears to be significant at the 1 percent level and positive which indicates holding all other variables at a constant level, students with a higher level of cumulative credit hours perform better than students with fewer cumulative credit hours. Therefore, we may infer that a senior student (higher cumulative credit hours) is more focused and serious about academic performance than a freshman student (lower cumulative credit hours). Course work completed to complete a student's major demonstrates higher commitment to the educational process, and, in turn, is related to academic success. This finding provides support to Sawyer (2010), Geiser and Santelices (2007), and O'Toole et al., (1999).

The next significant variable is a student's marital status. Similar to Li-Chen and Robert (1979), our study also indicates that married students are better academic performers than unmarried students in college. This variable is significant at the 10 percent level.

Age also showed a highly significant (at 1 percent level) positive relationship with a student's GPA. This study shows that older students are more likely to be better performers than younger students. There are a number of reasons why older students perform better than younger students. For example: increased self-efficacy perceptions (Chemers, Hu and Garcia, 2001), more focused cognitive abilities (Hughes and Smith, 1990), and increased selfdiscipline (Duckworth and Seligman, 2005). Therefore, these results indicate that in this sample, students' academic performance increases with age. However, another set of researchers found opposite results indicating older students do not perform well in the class because of factors such as time management (Macan, Shahani, Dipboye and Phillips, 1990), a deficit in study skills (Richardson, 1995) and higher liabilities (Birch and Miller, 2006). However, we fail to support this result in this study.

Students' cognitive abilities or high school GPA seems to have a strong positive and significant impact on students' academic performance. This result leads us to believe that a student with a higher high school GPA is more likely perform well in college and university courses. Students who are more involved in their high school academic experiences are most likely to continue that commitment into their college years. Walter (1986) and DeBerard et al., (2004) support the same finding.

The last significant variables are distance and distance squared. These two variables relate to OGPA differently; the first one related negatively and the second one related positively. The negative relationship between distance and OGPA in the model explains that as commuting distance increases, a student's OGPA is likely to drop while all other factors in the model remain constant. However, the distance squared variable is significant at the 1 percent level and positively enters into the equation. This means, OGPA is likely to increase for commuter students who have to travel a significant distance every day in order to attend classes. We have found that increasing travelling distance is related to students' OGPA. It may be that students who have to drive significant distance for classes are aware of the sacrifice they are making and want to make that sacrifice count by doing well academically. It may also be that the students who are living this far from the university may be taking online courses and therefore are not required to sacrifice family or study time to drive to campus. Further research is needed to explore the factors that under lie this finding. Students who live only a moderate distance from the university demonstrates lower cumulative GPAs. These lower GPAs may indicate less commitment to or involvement in academic life. Unfortunately we do not have information on these students' work commitments so we do not know what barriers to effective performance may be influencing them. 


\section{LIMITATIONS AND FUTURE RESEARCH NEEDS}

The limitation of this study is the data set. Since the data analyzed is related to one university, the results cannot be used to generalize students as a complete population. Community colleges for instance, are certain to have higher percentages of students who commute and the results from these schools might show a different trend. Also, since the students that are examined are all students of a university in Michigan, additional research is required to find the significance of a commuter's distance and his or her academic performance on a broader geographic scope. Students living in warmer climates such as Florida or California would not face the same weather-related barriers to commuting that students in Michigan face and so might not show as pronounced a relationship between commuting distance and GPA.

Table 2. Results: Overall Grade Point Average and Commuters

\begin{tabular}{|c|c|c|}
\hline Variable & Coefficient & Std. Error \\
\hline Constant & $1.98 * * *$ & 0.43 \\
\hline Distance & $-0.01 * * *$ & 0.00 \\
\hline Distance square & $0.00 * * *$ & 0.00 \\
\hline Cumulative credit hours & $0.01 * * *$ & 0.00 \\
\hline White & -0.09 & 0.09 \\
\hline Black & 0.04 & 0.15 \\
\hline Married & $0.25^{*}$ & 0.15 \\
\hline Age & $-0.06^{* *}$ & 0.02 \\
\hline Female & 0.07 & 0.04 \\
\hline HSGPA & $0.59 * * *$ & 0.05 \\
\hline R-Squared & 0.40 & \\
\hline Adjusted R-Squared & 0.39 & \\
\hline
\end{tabular}

\section{CONCLUSIONS}

This study attempted to begin research that would illuminate the reasons underlying the gap found when examining academic performance of commuters vs. non-commuting students. A commuter student's distance to campus and how much this distance affects a student in the classroom has not been closely examined before. Having found an initial example of a negative relationship between distance to campus and GPA, subsequent questions can be addressed: Is the lower academic performance simply due to distance? If so, then the development of more online course opportunities may help these students succeed. If the cause is more closely associated with distance combined with student skills, as evidenced by the relationship between high school and college GPA, then commuter students may need additional academic support resources. These resources might be provided in person or via the internet through online delivery. Both instructors and students should embrace the upward movement of technology and attempt to eliminate any barriers to ongoing advancement. If administrators and students are able to integrate technology into their classrooms efficiently, distance learning may be found to be the solution for commuter students and their limitations of academic achievement.

A key goal of research in this area is to identify barriers to commuter students' success and to then identify interventions that would help more students succeed in completing their degrees. Future research might include testing whether making support for students available online (rather than on-campus only) would enable more freshman success. If being a commuter means fewer opportunities for skill development, then providing support online would be a possible option for giving those commuters more access to skill building activities.

Results of this study also indicated that upper-division students had higher GPAs than lower-level students. This was hypothesized to be due to students' increased commitment to their education. Perhaps encouraging freshmen to pick a major, rather than allowing them to remain uncommitted, would encourage them to more completely engage with the institution and achieve greater long-term success. 


\section{AUTHOR BIOGRAPHIES}

Danielle Nelson is an alumna of the MBA program at Saginaw Valley State University. She graduated in (check year)

Kaustav Misra, Ph.D. is an Assistant Professor Economics at Saginaw Valley State University. His research has been published in refereed journals such as Entrepreneurship Theory and Practice, Economics of Education Review, The Journal of Socio-Economics, Journal of Family Business Management, International Entrepreneurship and Management Journal and Journal of Developmental Entrepreneurship.

Gail E. Sype, Ph.D. is an Associate Professor of Management and Marketing at Saginaw Valley State University. She is the author of numerous scholarly articles and books in management. Her research has been published in refereed journals such as Journal of Behavioral and Applied Management and International Journal of Business Research.

Wayne Mackie, Ph.D. is a Professor of Finance in the Accounting/Law/Finance Department at Saginaw Valley State University. Professor Mackie specializes in investment \& security markets of the world. His research interests include the security markets of the world changing environments; investments and investment anomalies. Professor Mackie's work has been cited in various journals on topics such as Developing a Homegrown Course Management System and Collaborating through Community Interactions: The CAMS Environment.

\section{REFERENCES}

Astin, A.W. 1984. "Student Involvement: A Developmental Theory for Higher Education.” Journal of College Student Involvement 40 no. 5: 518-529.

Bean, J.P. and Bradley, R.K. 1986. "Untangling the Satisfaction-Performance Relationship for College Students.” The Journal of Higher Education 57 no. 4: 393-412.

Birch, E.R. and Miller, P.W. 2006. "The Impact of HECS Debt on Australian Students' Tertiary Academic Performance." Education Research and Perspectives 33 no. 1: 1-32.

Bozic, R. 2007. "Making It through the First Year of College: The Role of Students' Economic Resources, Employment, and Living Arrangements." Sociology of Education 80 no. 3: 261-285.

Bozic, R. 2008. Student Employment during the Transition College in the United States. Research Report: RTI Press Publication RR-0001-0802.

Chemers, M., Hu, L. and Garcia, B.F. 2001. “Academic Self-Efficacy and First Year College Student Performance.” Journal of Education Psychology 93 no. 1: 55-64.

CompleteCollege.org. 2011 "Time is the Enemy." http://completecollege.org/?s=time+is+the+enemy.

DeBerard, M.S., Spielmans, G.I. and Julka, D.C. 2004. "Predictors of Academic Achievement and Retention among College Freshmen: A Longitudinal Study." College Student Journal 38.1: 66-80.

Duckworth, A.L. and Seligman, M.E.P. 2005. "Self-Discipline Outdoes IQ in Predicting Academic Performance of Adolescents." Psychological Science 16 no. 12: 939-944.

Fry, R. 2009. “College Enrollment Hits All-time High, Fueled by Community College Surge.” from Pew Research Center Publications: http://pewresearch.org/pubs/1391/college-enrollment-all-time-high-community-college-surge. (Retrieved August 5, 2012).

Geiser, S. and Santelices, M.V. 2007. "Validity of High School Grades in Predicting Student Success Beyond the Freshman Year: High-school Record vs. Standardized Tests as Indicators of Four-year College Outcomes.” Research and Occasional Paper Series: CSHE.6.07. Center for Studies in Higher Education. http://cshe.berkeley.edu/publications/docs/ROPS.GEISER._SAT_6.12.07.pdf Accessed on July 31, 2013.

Guerrero, A.A. 2010. "The Determinants of College Student Retention.” Dissertation published by UMI Dissertations Publishing.

Jacoby, B. and Garland, J. 2004/2005. "Strategies for Enhancing Commuter Student Success." Journal of College Student Retention, 6 no. 1: 61-79.

Kuh, G. D., Gonyea, R. M. and Palmer, M. 2001. “The Disengaged Commuter Student: Fact or Fiction?” Commuter Perspectives 27 no. $1: 2-5$.

Kuh, G.D. 2005. "Seven Steps for taking Student Learning Seriously.” Trusteeship May/June, pp. 20-24.

Li-Chen, M. and Robert, W. 1979. "Marital Status and Academic Performance in College." available at http://eric.ed.gov/?id=EJ207776 (accessed on July 31, 2013).

Lutta, J.M. 2008. "Factors that Influence Traditional-age College Students to Re-enroll in their Third Year at a Research Extensive University in the Southern Region of the United States." Dissertation, Louisiana State University and Agricultural and Mechanical College, Louisiana State University. 
Macan, T.H., Shahani, C., Dipboye, R.L. and Phillips, A.P. 1990. "College Students' Time Management: Correlations with Academic Performance and Stress", Journal of Education Psychology 84 no. 4: 760-768.

Newbold, J.J., Mehta, S.S. and Forbus, P. 2011. "Commuter Students: Involvement and Identification with an Institution of Higher Education.” Educational Leadership Journal 15 no. 2: 141-153.

Nonis, S.A. and Hudson, G.I. 2010. "Performance of College Students: Impacts of Study Time and Study Habits." Journal of Education for Business 85 no. 4: 229-248.

Nonis, S.A., Philhours, M.J. and Hudson, G.I. 2006. "Where Does the Time Go? A Diary Approach to Business and Marketing Students' Time Use.” Journal of Marketing Education 28 no. 2: 121-134.

O'Toole, D., Peterson, S. and Wetzel, J.N. 1999. "Factors Affecting Student Retention Probabilities: A Case Study.” Journal of Economics and Finance 23 no. 1: 45-55.

Pascarella, E.T., Terenzini, P.T. and Wolfle, L.M. 1986. "Orientation to College and Freshmen Year Persistence/Withdrawal Decisions." The Journal of Higher Education 57 no. 2: 155-175.

Richardson, J.T.E. 1995. "Mature Students in Higher Education: II. An Investigation of Approaches to Studying and Academic Performance." Studies in Higher Education 20 no. 1: 5-17.

Saenz, T., Marcoulides, G.A., Junn, E. and Young, R. 1999. "The Relationship between College Experience and Academic Performance among Minority Students." The International Journal of Educational Management 13 no. 5: 199-207.

Sawyer, R. 2010. "Usefulness of High School Average and ACT Scores in Making College Admission Decisions." ACT Research Report Series 2010-2. http://www.act.org/research/researchers/reports/pdf/ACT_RR2010-2.pdf. (Accessed on July 31, 2013).

Tenhouse, A.M. 2011. "Commuter Students-Commuter Student Challenges." http://education.stateuniversity.com/pages/1875/Commuter-Students.html. (Retrieved May 16, 2012).

Tinto, V. 1999. “Taking Student Success Seriously: Rethinking the First Year of College.” NACADA Journal 19 no. 5: 5-9.

Walter, A. 1986. "Gender and Campus Race Differences in Black Student Academic Performance, Racial Attitudes and College Satisfaction.” http://eric.ed.gov/?id=ED268855. 


\section{NOTES}

